\title{
A CAMINHO DE BAYREUTH: A MÚSICA NA OBRA DE MACHADO DE ASSIS
}

Artigo originalmente publicado na Revista Hispánica Moderna, editada pela Columbia University, de Nova York, v. 34, n. 3, em julho de 1968, p. 776-790.

\author{
RAYMOND S. SAYERS \\ Queens College \\ Nova York, NY, Estados Unidos \\ APRESENTAÇÃO DE MARCELO DIEGO \\ Universidade Federal do Rio de Janeiro \\ Rio de Janeiro, Rio de Janeiro, Brasil
}

Resumo: Neste ensaio inaugural, Raymond S. Sayers acompanha o processo de educação musical de Machado de Assis, ao mesmo tempo que observa a progressiva sofisticação das referências musicais no interior da ficção machadiana. Depois de mapear a paisagem sonora complexa em que se inserem tanto o escritor quanto seus narradores e suas personagens, o ensaísta aprofunda-se na análise do diálogo entre o romance de Machado de Assis e a ópera de Richard Wagner.

Palavras-chave: Música no Brasil; literatura e outras artes; ópera alemã; Richard Wagner; Machado de Assis.

\section{HEADING TO BAYREUTH: MUSIC IN THE WORK OF MACHADO DE ASSIS}

Abstract: In this inaugural essay, Raymond S. Sayers follows Machado de Assis's process of musical education, while observing increasingly sophisticated references to music in Machadian fiction. After mapping the broader soundscape in which the writer, his narrators and characters exist, the essayist focuses on the dialogue between Machado de Assis's novels and Richard Wagner's operas.

Keywords: Music in Brazil; literature and other arts; German opera; Richard Wagner; Machado de Assis. 
Machado de Assis em Linha - Universidade de São Paulo http://machadodeassis.fflch.usp.br

Raymond S. Sayers foi um pioneiro no campo dos estudos literários brasileiros nos Estados Unidos e um dos críticos de sua geração cujas ideias se mantêm mais atuais. Nascido em 1912, na cidade de Nova York, lá mesmo se formou e desenvolveu a maior parte de sua carreira. Sua tese de doutorado na Columbia University, The Negro in Brazilian Literature, publicada em inglês em 1956 (pelo Hispanic Institute in the United States, de Nova York) e em português em 1958 (como O negro na literatura brasileira, com tradução de Antônio Houaiss, pelas Edições O Cruzeiro, do Rio de Janeiro), foi uma das primeiras pesquisas acadêmicas a dar visibilidade à presença negra na produção e no meio literários brasileiros.

Nas décadas seguintes, Sayers contribuiu ativamente para a difusão da cultura brasileira nos Estados Unidos, tanto como professor - ensinando português na Columbia University e literaturas de língua portuguesa no Queens College, da City University of New York -, quanto como pesquisador - organizando os volumes Portugal and Brazil in Transition (Minneapolis: University of Minnesota Press, 1968) e Cecília Meireles: poemas em tradução / poems in translation (traduções de Henry Hunt Keith e Raymond S. Sayers, com a assistência de Francisco de Sousa Neves e Antonio Salles Filho. Washington: Brazilian-American Cultural Institute, 1977).

No Brasil, Sayers tornou-se conhecido principalmente pelos Onze estudos de literatura brasileira (tradução de Roberto Raposo. Rio de Janeiro: Civilização Brasileira, 1983), uma recolha de ensaios e comunicações, divulgadas anteriormente em periódicos e eventos acadêmicos. Aposentado precocemente por motivos de saúde, mudou-se para Madison, onde colaborou para a consolidação do programa de estudos brasileiros da University of Wisconsin e veio a falecer, em 1994; entretanto, sempre que podia, voltava à sua cidade natal, para visitar os amigos e a sua adorada casa de ópera.

O ensaio "A caminho de Bayreuth: a música na obra de Machado de Assis" apareceu em 1968, na Revista Hispánica Moderna, e em 1983, ligeiramente modificado, como um capítulo dos Onze estudos de literatura brasileira, intitulado "A música na obra de Machado de Assis". O papel da música na ficção machadiana já havia sido notado por diversos críticos, desde os primeiros que se debruçaram sobre a obra do autor, porém sempre de maneira incidental, tratando-a como elemento coadjuvante, e não como objeto central da análise; Sayers foi o primeiro a dar relevo próprio ao tema e a abordá-lo de modo sistemático e rigoroso. 
Como o título do ensaio revela, "A caminho de Bayreuth" descreve um percurso - o da educação musical de Machado de Assis -, cujo estágio final seria o do diálogo com as composições de Richard Wagner. Generoso, o ensaísta apresenta as formas, os gêneros, os autores, os repertórios com os quais o escritor se foi familiarizando (e os quais foi incorporando à sua escrita) paulatinamente, ao longo do tempo, permitindo assim que também o leitor leigo no assunto se familiarize com eles. Isso porque as análises de Sayers, não obstante o caráter eminentemente literário, são alicerçadas em sólida cultura musical, o que permite ao ensaísta, por exemplo, apontar erros cometidos pelo escritor, quando este se refere equivocadamente a determinadas formas musicais.

Como uma partitura para piano, o ensaio de Sayers possui um fio condutor, uma mão direita, que é a escuta da música no romance e no conto de Machado de Assis; e um acompanhamento, uma mão esquerda, que são os ecos musicais recolhidos na crônica, na crítica, na correspondência e na biografia do escritor. Nesse segundo plano, revelam-se cruciais as redes de sociabilidade das quais fazia parte Machado, como a do Club Beethoven e a do grupo de amigos de Artur Napoleão. Cabe lembrar, por fim, que a despeito de o ensaio dedicar maior espaço à presença da música erudita (principalmente a ópera, as criações para orquestra e para piano) na obra e na vida de Machado de Assis, nem por isso ele deixa de lançar luzes sobre a presença da música popular (polcas, pregões, canções de lavadeiras, cantigas, cantilenas, cantares d'África etc.). Como na própria escrita machadiana, na de Sayers, a linha entre essas duas categorias é tênue e constantemente tensionada.

A Machado de Assis em linha procurou, exaustivamente, por eventuais herdeiros de Raymond S. Sayers, mas não conseguiu localizar algum. Consultada, a Revista Hispánica Moderna, na pessoa do seu editor executivo, Hernán Díaz, também relatou desconhecer possíveis detentores dos direitos autorais do crítico e autorizou a republicação do artigo. Assim, fica registrado publicamente o reconhecimento da Machado de Assis em linha às contribuições feitas por Raymond S. Sayers ao campo dos estudos machadianos, em específico, e dos estudos brasileiros no exterior, de maneira geral. 


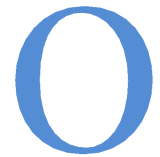

estudioso da cultura brasileira não pode nunca deixar de notar que a música ocupa um lugar de grande relevância na literatura do século XIX. Nos romances da vida da cidade, não faltam episódios cujo palco é o Teatro Lírico, o Teatro Provisório, ou algum outro teatro que durante o século se utilizava para a apresentação de óperas, e outros episódios, que têm lugar em saraus familiares, incluem quase sempre solos ou duetos de canto e piano. Uma característica do romance regional de Alencar, Franklin Távora, Bernardo Guimarães e Herculano Inglês de Sousa é a presença de personagens que cantam as cantigas tradicionais da região descrita. Entre as prendas das heroínas dos romances urbanos, uma das mais apreciadas é o talento musical, que é quase tão importante como a beleza física e a juventude. É indubitável que essa preocupação indica a profunda significação da música no caráter da vida nacional, e a sua maior integração nessa vida do que as outras artes, hipótese apoiada pela pouca importância atribuída na ficção às artes gráficas e à escultura, que são apenas mencionadas em Alencar, e que, aparecendo em dois romances de Machado, Helena e Memorial de Aires, funcionam no desenvolvimento da trama e no estabelecimento da atmosfera, mas não como elementos estéticos independentes. Até a poesia e o teatro dramático ocupam um lugar secundário com respeito à música. $\mathrm{O}$ mesmo Machado de Assis se queixa em 1865 que todos proclamam a necessidade de um teatro lírico e esquecem o teatro dramático:

[...] eu não posso deixar de notar uma singularidade; é o afã com que todos clamam por um teatro lírico, e o desdém com que quase todos se esquecem de um teatro dramático. Entretanto, ninguém porá dúvida que, se o teatro lírico é o agradável e talvez o supérfluo, o teatro dramático é mais que o útil, é o necessário. (ASSIS, 1942b, p. 289)

Em 1878, nas Notas semanais, Machado documenta mais uma vez essa preferência dos cariocas pela ópera às melhores peças do teatro inglês ou francês e observa que o amor do carioca pela música começa na infância:

[...] sabe toda a gente que, abaixo do doce de coco, o que o fluminense mais adora é a boa música. Haverá, e não raros, que jamais possam suportar uma cena do Cid ou um diálogo do Hamlet, que os achem supinamente amoladores, tanto como os antigos dramalhões do Teatro de S. Pedro; mas nenhum há que se não babe ao ouvir um dueto. E isto vem desde a infância; nas escolas aprende-se a ler a carta de nomes 
Machado de Assis em Linha - Universidade de São Paulo

http://machadodeassis.fflch.usp.br

cantando; e ninguém ignora que a primeira manifestação do menino carioca é o assobio. (ASSIS, 1959c, p. 435-436)

Esse amor pela ópera é documentado também na ficção e nas crônicas. Na História de 15 dias de 1877, Machado (ASSIS, 1959c, p. 387) relata que o carrilhonista da Igreja da Lapa dos Mercadores toca árias operáticas enquanto o padre diz missa, de modo que "estar-se à missa ou nas cadeiras do Alcazar, salvo o respeito devido à missa, era a mesma cousa." No conto "O diplomático", uma personagem diz que "os moleques assobiam na rua" a Casta diva (ASSIS, 1959b, p. 523).

Não se sabe se Machado em criança assobiava na rua a famosa ária de Bellini; é possível, porque a primeira audição de Norma foi em 1844, quando ele tinha cinco anos, e já seria capaz de andar assobiando pelas ruas, mas é fato que sua vida e sua obra demonstram um amor persistente pela música de toda espécie - popular, folclórica e clássica, vocal e instrumental - e que ele tinha muitos amigos que eram músicos, inclusive Artur Napoleão, o menino prodígio que se tornou um dos mais célebres pianistas do século. Esse interesse, que se ia desenvolvendo durante sua vida, é evidente na crítica musical que fez no início da sua carreira, e nas frequentes referências à música nos primeiros livros, e o seu desenvolvimento é patenteado mais tarde em contos em que procura simbolizar problemas de estética, nas suas tentativas para imitar formas musicais em outros contos, e, finalmente, no seu último romance, Memorial de Aires, que dá a impressão de ser uma refundição em prosa do drama musical de Wagner Tristan und Isolde. Se Machado não é o ficcionista brasileiro que mais intimamente conhecesse a música, devemos reconhecer que não há outro, salvo Mário de Andrade, que a tenha amado mais ou que tenha dado mais provas na sua obra de seu interesse por todos os aspectos da música.

Não é demais afirmar que Machado fez uma grande contribuição para o desenvolvimento do gosto musical, e que a leitura das suas obras pode servir muito bem para o estudo da história da música no Brasil. Quando ele nasceu, em 1839, o teatro lírico tinha existido no Rio desde a inauguração em 1813 do Real Teatro de São João com o Juramento dos Numes de Marcos Portugal, compositor português que acompanhou a família real portuguesa ao Brasil em 1807 (SILVA, 1938, p. 27). Depois da Independência, a ópera italiana parece ter começado com a primeira representação do Otelo de Rossini, em 1828 (SILVA, 1938, p. 444). A partir da década de 1840, o amor pela ópera terá aumentado tanto que uma grande parte do repertório do contemporâneo teatro lírico italiano terá sido representada no Rio, Auber e outros 
Machado de Assis em Linha - Universidade de São Paulo

http://machadodeassis.fflch.usp.br

compositores franceses são conhecidos na década de 1860, e a época de Wagner começa em 1883, com a primeira audição de Lohengrin no teatro D. Pedro II. De início, é evidente que a única música séria, exceto a sacra, cantada nas igrejas, era a ópera, e essa situação continuou até bem depois dos meados do século. O desenvolvimento de outras formas musicais foi lento, e elas não enraizaram bem até muito mais tarde. Artur Napoleão disse em 1857 que havia no Rio poucos músicos e menos professores; de professores de piano havia um só que era razoavelmente bom e outro que era "[...] bom músico, embora não grande pianista." (FRIAS, 1913, p. 99). Mas uma revolução no gosto musical começou com a chegada, em 1855, do grande pianista Thalberg, de Artur Napoleão em 1857 (quando tinha apenas quatorze anos de idade), e do pianista americano Louis Moreau Gottschalk, que passou vários meses no Rio e lá morreu em 1869. Foi a época das transcrições para piano de Franz Liszt, e dos concertos gigantescos, num dos quais, organizado por Gottschalk, se apresentaram quinhentos músicos que tocaram uma peça sinfônica, composta por ele, no clímax da qual se ouviram descargas de canhões (FRIAS, 1913, p. 22). Mau gosto, evidentemente, mas um mau gosto que serviu para publicizar a música instrumental e sinfônica e para preparar o caminho para os concertos mais sérios que começaram a ouvir-se na década de 1880, com a organização, em 1882, do Clube Beethoven. O Clube promoveu quatro grandes concertos sinfônicos e muitos concertos de música de câmara e recitais, dando um forte impulso à vida musical. Em 1883, se fundou a Sociedade de Concertos Clássicos, e, em 1887, foi apresentada a primeira série de concertos públicos, chamada Os Concertos Públicos (AZEVÊDO, 1956, p. 94-97).

A colaboração de Machado em toda essa atividade foi contínua. A partir de 1859, quando tinha apenas vinte anos, começou a escrever crítica teatral e musical, tratando nos primeiros artigos de óperas italianas como I lombardi, I puritani, e Norma; nos anos seguintes ia criticar óperas de Verdi: Ernani, Um ballo in maschera e outras (ASSIS, 1944, p. 34-39 e 51; ASSIS, 1942a, p. 66-67, 76, 91 et seq). Os maiores admiradores de Machado não podem senão concordar que essas críticas, as primícias da sua pena, são muito imaturas. Conforme a tendência da época, ele presta mais atenção aos cantores, sobretudo às sopranos, do que à música, e na sua discussão das partituras se limita a breves generalidades. Fala em "rasgos de harmonia", usa expressões como "os mais belos da literatura musical" (ASSIS, 1942a, p. 56-57), e ao criticar a interpretação de uma soprano do papel de Norma, diz que "seus 
Machado de Assis em Linha - Universidade de São Paulo

http://machadodeassis.fflch.usp.br

belos dotes de canto e de arte foram empregados de um modo, não a satisfazer, mas a entusiasmar a plateia." (ASSIS, 1942a, p. 91).

Nesses escritos, Machado não revela quaisquer conhecimentos da arte da música. Anos depois, em 1892, quando havia muito tempo que não exercia as funções de crítico, ridicularizaria semelhante jornalismo numa crônica em que fala na primeira representação de Tannhäuser. Diz que não tinha ouvido a ópera, mas que se a fosse assistir algum dia, se prepararia de antecedência com algumas opiniões sólidas e francesas, para fazer uma opinião prévia. Ouviria a música com muita atenção, porque se trata de uma grande solenidade artística. "A arte é uma religião. O gênio é o sumo sacerdote." E, então, durante os intervalos, visitaria os camarotes e exprimiria a sua opinião às senhoras:

Aquela entrada dos fagotes, lembra-se? Admirável! Os coros, o duo, os violinos, oh! o trabalho dos violinos, que cousa adorável, com aquele motivo obrigado; la la la tra la la, la, tra la la... Há neste ato inspirações que são, com certeza, as maiores do século. (ASSIS, 1959c, p. 575)

Entretanto, a sua educação musical progredia, e o seu interesse pela música não diminuía. Na década de 1860 fez uma amizade firme e duradoura com Artur Napoleão e começou a frequentar uma casa da rua da Quitanda para participar de saraus literários e musicais. Entre os músicos que assistiam as reuniões, e que eram os mais conhecidos da época, estavam Napoleão, Schramm, também pianista, Moniz Barreto, violinista, e Reichert, flautista (FRIAS, 1913, p. 156-157). Já em 1866, o seu futuro cunhado, Faustino Xavier de Novais, lhe dirigiu uma carta em que fala dos conhecimentos musicais de Machado (SOUSA, 1958, p. 14). Terá ouvido os maiores artistas estrangeiros, que iam para o Rio com mais frequência, trazendo à atenção do público o repertório de música instrumental e sinfônica. Num concerto em 1870, Adelina Patti cantou, Pablo Sarasate tocou e Theodore Ritter regeu a Sinfonia Pastoral de Beethoven, ouvida no Rio pela primeira vez 61 anos depois de sua publicação (BIBLIOTECA NACIONAL, 1962, p. 96). Machado terá participado ativamente do trabalho do Clube Beethoven. Em carta datada de 1887, diz ter sido reeleito para a diretoria do Clube, e talvez tenha sido secretário, porque existe um rascunho de carta em francês de sua autoria, mas sem data, em que comunica a uma pessoa residente na França a notícia da remessa do diploma de sócio correspondente do Clube (ASSIS, 1959c, p. 1055). Segundo Jean-Michel Massa, Machado foi tesoureiro do Clube (ASSIS, 1965, p. 527). 
Machado de Assis em Linha - Universidade de São Paulo http://machadodeassis.fflch.usp.br

Participando da evolução dos conhecimentos musicais cariocas, nas Crônicas - fiel espelho do gosto público - Machado já fala em 1876 na música de Wagner, mas com intenção satírica (ASSIS, 1959c, p. 383 e 385). Em 1878, no conto "Um machete", se refere à música alemã, e em "Vinte anos! Vinte anos!", conto publicado em 1884, menciona Wagner (ASSIS, 1959b, p. 830 e 950). Lohengrin já fora representado em 1883 "com tédio", diz Luiz Heitor, mas em 1892 a primeira audição do Tannhäuser fora recebida "com entusiasmo" (AZEVÊDO, 1956, p. 98). Em Dom Casmurro e livros posteriores, são frequentes as referências a compositores alemães, ao passo que, antes da década de 1880, há apenas duas ou três referências à música alemã, uma em 1862, a Mozart (ASSIS, 1942a, p. 319-320), e outra em 1872, a Weber (ASSIS, 1959a, p. 94). Naquela ele cita outro crítico que compara a carreira de menino prodígio de Artur Napoleão com a de Mozart. Napoleão, sempre o amigo de Machado, ouviu o Ring des Nibelungen em 1875, e pode ter sido um dos primeiros músicos a discutir Wagner com Machado (FRIAS, 1913, p. 233).

O crescente entusiasmo pela música alemã é sintomático do novo interesse pela cultura alemã em geral, estimulado por Tobias Barreto e Sílvio Romero. Entre os adeptos do novo movimento se achava Machado de Assis. Em "Letra vencida", conto publicado em 1882, o herói parte do Brasil para estudar em Heidelberg (ASSIS, 1959b, p. 871), e em 1883 Machado, sempre desejoso de aprender novas línguas, estudava alemão, enchendo um caderno de exercícios que demonstram que ele fizera rápidos progressos em três meses (MINISTÉRIO DA EDUCAÇÃO E SAÚDE, 1939, p. 101-102). Não consta que tenha procurado conhecer a literatura alemã em língua original, mas cita repetidamente na sua obra os grandes escritores alemães. Começa a citar Goethe logo no princípio de sua carreira, e durante toda a vida serve-se de epígrafes e citações goetheanas (ASSIS, 1959a, p. 242). Em 1863, traduziu uma poesia de Heine, provavelmente baseando-se numa versão francesa, mas em 1896 tem suficientes conhecimentos de alemão para citar o poeta no original (SOUSA, 1958, p. 217-218; ASSIS, 1959c, p. 741). Estava lendo Schopenhauer em 1908, e antes demonstrara certa familiaridade com Schiller e Hegel (ASSIS, 1959c, p. 1118; ASSIS, 1959b, p. 448-449). Em 1895, chegou ao ponto de escrever numa crônica uma frase em alemão, errando o gênero do substantivo: "Der [sic] närrische Schiff." (ASSIS, 1959c, p. 678).

Até o fim da sua vida terá ouvido quase todos os grandes compositores; conhecia a música como amador e as óperas talvez tão bem como aqueles operários italianos que frequentam o galinheiro da Scala de Milão e que, 
Machado de Assis em Linha - Universidade de São Paulo

http://machadodeassis.fflch.usp.br

sabendo cantarolar as partituras de todo o repertório italiano, têm noções da técnica vocal, mas ignoram completamente a teoria musical. Há indicações na ficção machadiana de ele não ter nunca procurado aprender a teoria ou a técnica de qualquer instrumento. No máximo, terá possuído algumas ideias sobre as formas musicais, colhidas da conversação de músicos que conhecia ou dos concertos que assistia. Em "Trio em lá menor", ele emprega a forma da sonata na construção do conto, dividindo-o em quatro tempos: adagio cantabile, allegro ma non troppo, allegro appassionato, minuetto. Embora o fato não tenha a menor importância com relação ao valor literário do conto, ele fez um erro na forma da sonata, porque uma sonata de quatro movimentos não termina nunca com o minuetto (THOMPSON, 1956). Em "Cantiga velha", ele diz: "duas ou três oitavas do 'Caia no beco""; evidentemente, uma pessoa com conhecimentos mais exatos diria "dois ou três compassos" (ASSIS, 1959b, p. 920). Em Esaú e Jacó, há um belo trecho em que Flora toca uma sonata para esquecer a agitação produzida pela revolução republicana. Embora escreva uma frase melódica, Machado não nomeia o compositor da sonata, sem dúvida porque tal sonata não existe (ASSIS, 1959a, p. 964-965). Conhecendo o repertório do piano, não teria inventado nem a melodia, nem a sonata. Em dois interessantes contos que tratam do tema da inspiração musical, "Cantiga de esponsais" e "Um homem célebre", ao se referir à composição de peças musicais, ele fala de uma maneira que sugere a literatura, e não a música. $O$ assunto do primeiro é que o melhor regente de orquestra do Rio, desejando compor uma peça que exprima a inspiração despertada nele pelo amor, não consegue escrever mais do que uma curta frase, que fica interrompida na nota lá; no segundo, um pianista com muito talento para compor polcas não consegue escrever um requiem. O problema não é bem apresentado, em termos musicais, porque embora Machado nos convença que os protagonistas sabem reger uma orquestra ou tocar piano, parece não ocorrer-lhe que executar uma peça num instrumento ou com uma orquestra é uma coisa, e compor é outra; parece confundir, também, a simplicidade de uma forma musical que se compõe espontaneamente, como a polca, com a de uma obra que exige muita erudição musical na sua composição, como o requiem.

É esta falta de conhecimentos técnicos e exatos que deve explicar o que é aparentemente uma estranha anomalia estilística na ficção machadiana: a escassez de metáforas musicais, ao passo que através dos seus romances e contos, mormente nos do período central da sua carreira, entre 1881 e 1891, o emprego da metáfora é um recurso de que ele lança mão constantemente, 
Machado de Assis em Linha — Universidade de São Paulo

http://machadodeassis.fflch.usp.br

havendo centenas relacionadas ao dinheiro, ao comércio, às loterias, à técnica literária, aos desgastes produzidos pelo tempo. Entre todas as metáforas e símiles que encontramos nos contos e romances de Machado, com exceção de algumas tão familiares que perderam a qualidade de metáfora, contei apenas treze em que se empregam termos musicais, e, dessas, só uma é anterior a 1882; não há nenhuma metáfora musical nas 308 metáforas que contei em Brás Cubas. No Memorial de Aires, romance em que a música faz um papel da maior importância, há apenas uma metáfora musical:

A diplomacia que exerci em minha vida era antes função decorativa que outra cousa; não fiz tratados de comércio nem de limites, não celebrei alianças de guerra; podia acomodar-me às melodias de sala ou de gabinete. Agora vivo do que ouço aos outros. (ASSIS, 1959a, p. 1073)

Dessas treze metáforas, não há nenhuma que indique que Machado possuísse conhecimentos da técnica musical, embora haja algumas que são das mais originais e cintilantes que compôs:

Depois, foi andando lentamente, pensando em várias mulheres que podia escolher muito bem, para executar, a quatro mãos, a sonata conjugal, música séria, regular e clássica. Chegou a pensar na filha do major, que apenas sabia umas velhas mazurcas. De repente, ouvia a guitarra do pecado, tangida pelos dedos de Sofia, que o deliciavam, que o estonteavam, a um tempo. (ASSIS, 1959a, p. 632) ${ }^{1}$

Em Dom Casmurro encontramos uma metáfora muito mais desenvolvida, em que um tenor italiano compara a vida a uma ópera italiana; os termos da comparação, porém, são literários, e a comparação se reporta à trama ou parte dramática da ópera, e não à música (ASSIS, 1959a, p. 736-738).

Pode-se concluir que não conhecia a música tecnicamente, mas que evidentemente sentiu o seu encanto durante toda a sua vida, e como eu assinalasse acima, ele sabia empregar bem a música como elemento dos seus romances e contos. Parece que teria gostado de conhecê-la bem. Em certa altura, a personagem que mais se parece com o velho Machado, o conselheiro Aires, confessa:

\footnotetext{
${ }^{1}$ Compare-se a frase em Helena: "Estácio encetou uma conversa geral, que não passou de um simples duo." (ASSIS, 1959a, p. 194).
} 
Machado de Assis em Linha — Universidade de São Paulo

http://machadodeassis.fflch.usp.br

A música foi sempre uma das minhas inclinações, e, se não fosse temer o poético e acaso o patético, diria que é hoje uma das saudades. Se a tivesse aprendido, tocaria agora ou comporia, quem sabe? Não me quis dar a ela, por causa do ofício diplomático, e foi um erro. [...] Agora vivo do que ouço aos outros. (ASSIS, 1959a, p. 1073)

Quando escreveu esse parágrafo, no fim da vida, Machado tinha descoberto todos os segredos da sua arte, e a sua bagagem literária se compunha de teatro, ensaio, poesia e ficção. Tinha sido romântico e realista, e tinha escrito ficção psicológica, satírica e simbólica, mas sentia que havia alguma coisa na música que não podia existir na literatura, e que não encontrava na pintura, de que havia feito algumas experiências em Helena e Memorial de Aires. ${ }^{2}$ A música era uma arte diferente. Atraía-o o desprendimento da música e a sua qualidade de arte pura, desligada da dependência de objetos, que restringe a liberdade das outras artes. Parecialhe uma arte que não sofria limitações de espaço, e sendo a arte do tempo, podia simbolizar a intemporalidade. Movia-se num plano superior ao da literatura. Por essa qualidade abstrata, Machado parece tê-la considerado a mais apropriada para exprimir problemas estéticos, sobretudo os da criação artística. Essa qualidade de abstração se revela no episódio de Esaú e Jacó já mencionado, em que Flora toca uma sonata na noite da revolução de 1889:

Escolheu não sei que sonata. Tanto bastou para lhe tirar o presente. A música tinha para ela a vantagem de não ser presente, passado ou futuro; era uma cousa fora do tempo e do espaço, uma idealidade pura. $[\ldots]$

Também se pode achar na sonata de Flora uma espécie de acordo com a hora presente. [...] A sonata trazia a sensação da falta absoluta de governo, a anarquia da inocência primitiva naquele recanto do Paraíso que o homem perdeu por desobediente, e um dia ganhará, quando a perfeição trouxer a ordem eterna e única. Não haverá então progresso nem regresso, mas estabilidade. (ASSIS, 1959a, p. 965)

Numa frase do Memorial, Machado retorna a essa interpretação da música como uma coisa fora do tempo e do espaço, sendo, portanto, uma arte superior: "vantagem grande da música, que fala a mortos e ausentes." (ASSIS, 1959a, p. 1117).

\footnotetext{
${ }^{2}$ Helena pinta um quadro que tem importância no desenvolvimento do enredo; o quadro de Fidélia é utilizado pelo autor como um dos símbolos do mar que abundam no Memorial.
} 
Machado de Assis em Linha - Universidade de São Paulo

http://machadodeassis.fflch.usp.br

Só raras vezes Machado trata de questões estéticas, e a leitura da sua obra não dá a impressão de que ele as tenha estudado profundamente. $\mathrm{O}$ parágrafo que acabo de citar contém umas ideias transcendentais que vêm representadas pela arte da música. Voltou-se para a música também quando quis simbolizar certas ideias ligadas à inspiração artística que o interessavam. A absorção do artista pela sua arte, ou seja, o fato de a arte ser uma força mais poderosa na nossa vida do que o dinheiro, o amor, ou os laços de família, é salientado em certo episódio de Dom Casmurro. Bento, o protagonista, passa por casualidade por uma barbearia, onde para, ao ouvir um violino, tocado por um dos barbeiros. Este, sabendo que é ouvido, continua a tocar, apesar da chegada de fregueses, e perde duas barbas. Bento reflete que qualquer artista, em situação parecida, faria a mesma coisa, e não só isso, mas ainda que a mulher do homem o estivesse traindo bem à vista, não deixaria de tocar, tão forte é o poder da arte: "[...] então é que ele, todo arco, todo rabeca, tocaria desesperadamente. Divina arte!" (ASSIS, 1959a, p. 854). Em outra personagem que é excelente violoncelista, Machado simboliza a solidão do artista diante da incompreensão do mundo. Em "O machete", conto publicado no Jornal das Famílias em 1878, ele relata a história de um músico completamente dedicado ao seu instrumento, o violoncelo. Ele e a mulher se amavam, mas ela não apreciava a arte dele e não sentia qualquer entusiasmo pelo violoncelo; o talento do marido e a arte requintada com que tocava o instrumento não encontravam eco na sua alma vulgar. Conheceram um estudante de direito, e amador da música, que tocava o machete, de todos os instrumentos de cordas talvez o mais simples. O estudante não tinha a capacidade artística do marido, mas pela graça com que tocava, e pela maneira com que movia o corpo, soube agradar à mulher, que acabou fugindo com ele, abandonando filho e marido (ASSIS, 1959b, p. 827-835). Em dois contos de que já falei, "Cantiga de esponsais" e "Um homem célebre", o tema é a criação artística. Ambos os protagonistas são pianistas, e o de "Um homem célebre" é também um genial compositor de polcas, mas nenhum dos dois consegue compor a música séria que admiram. A razão, segundo o autor, é que não possuem o vocabulário que precisam para traduzir a inspiração em música. Diz Machado:

há duas sortes de vocação, as que têm língua e as que a não têm. As primeiras realizam-se; as últimas representam uma luta constante e estéril entre o impulso interior e a ausência de um modo de comunicação com os homens. Romão era destas. Tinha a vocação íntima da música; trazia dentro de si muitas óperas e missas, um mundo de 
Machado de Assis em Linha - Universidade de São Paulo

http://machadodeassis.fflch.usp.br

harmonias novas e originais, que não alcançava exprimir e pôr no papel. (ASSIS, 1959b, p. 384)

Esse parágrafo deveria significar que o músico sentia uma íntima inspiração musical, mas que não possuía suficientes conhecimentos técnicos para poder traduzir essa inspiração em compassos e notas, que lhe faltava a língua do compositor. Machado, entretanto, para representar essa ideia, deveria ter escolhido um compositor, e não um pianista. É possível ser bom músico e tocar muito bem sem saber compor, e o fato de Romão ter estudado piano não quer dizer que possuísse os conhecimentos necessários para compor peças originais. Apesar desse defeito, o problema abordado em "O machete" é interessante: se dentro da alma podem existir melodias que não são expressas em termos musicais ou em alguma outra forma artística, embora Machado, por não ter analisado suficientemente a diferença entre a composição e a execução de uma peça não consiga exprimi-lo satisfatoriamente. O mesmo pode dizer-se com referência a "Um homem célebre": a forma escolhida para expor o problema não pode representá-lo. Nesse conto, o protagonista compõe polcas com grande êxito, mas nunca consegue compor um requiem em memória da defunta mulher. É claro que não há comparação entre os problemas relacionados à composição de uma polca - que consiste de uma melodia singela e curta - e um requiem; este é elaborado à base de anos de estudo de música, e aquele pode surgir espontaneamente na mente de uma pessoa sem cultura musical.

Se as noções de Machado a respeito da música eram as de um amador inteligente que nada sabia da teoria ou composição e pouco das formas da música, nem por isso podemos negar que a música ocupa lugar importante e interessante na sua ficção. Utiliza-a no desenvolvimento de muitas personagens e na construção de cenas importantes; também a emprega sutilmente para estabelecer o tom ou atmosfera de certos episódios, para introduzir elementos que não deseja longamente, e para ligar o presente com o passado por meio de seu incomparável poder associativo. Nos primeiros romances, a utilização da música é relativamente simples e comparável com a maneira como Alencar a empregava na sua ficção urbana: as prendadas heroínas sabem tocar piano divinamente e com frequência têm belas vozes; certas cenas se desenrolam durante audições de óperas; em quase todos os romances há saraus musicais. Mais tarde, Machado procura elementos ou formas musicais para a construção dos contos e romances, chegando no fim da carreira a lançar mão de todos os recursos musicais que possuía para escrever Memorial de Aires. 
Machado de Assis em Linha - Universidade de São Paulo

http://machadodeassis.fflch.usp.br

Fica subentendido que todas as heroínas e muitas personagens secundárias dos seus romances sabem tocar, porque espelham a vida da aristocracia e da alta burguesia do Império, e como diz Palha certo dia, a música (e o francês) "por mais supérfluas que lhe parecessem aquelas prendas, eram o mínimo dos adornos de uma educação de sala" (ASSIS, 1959a, p. 614). Também parece ser subentendido que sabem cantar, como se depreende de um trecho de Helena:

possuía Helena algumas prendas de sociedade, que a tornavam aceita a todos [...]. Não falo da magnífica voz de contralto, nem da correção com que sabia usar dela [...]. Era pianista distinta, sabia desenho, falava corretamente a língua francesa, um pouco a inglesa e a italiana. (ASSIS, 1959a, p. 196)

Pode ser objetado que Helena é uma concepção da escola romântica, uma imitação da Augusta de Onde está a felicidade?, mas as outras heroínas como Capitu, Sofia e Fidélia pertencem aos livros da fase realista e também possuem essas prendas. Toca-se e canta-se em todos os saraus, tanto nos palacetes dos ricos como em casas mais humildes, e a música ou a vida musical são um assunto infalível de conversação. Em geral, os convidados aos saraus apreciam a música; só num conto que pode ser classificado como de cor local, "As bodas de Luís Duarte", o autor apresenta uma personagem para quem é um martírio escutar um solo musical e, sobretudo, uma soprano; em compensação, no mesmo sarau, para ouvir bem a cantora, um outro rapaz "que na sua qualidade de poeta, devia amar a música, aproximou-se do piano e inclinou-se sobre ele na posição melancólica de um homem que conversa com as musas." (ASSIS, 1959b, p. 195-196). Todas essas reuniões têm acompanhamento musical; atrás da conversação ouvimos a música das quadrilhas, das polcas, das valsas que se dançavam, e a voz da contralto ou o solo do pianista. Isso está esboçado numa cena de Quincas Borba, em que Sofia, querendo terminar uma conversa com Rubião, lhe estende a mão e se despede, mas "O piano continuava; Rubião notou-lhe esta circunstância. Enquanto ouviam tocar, não viriam ter com eles." Sofia continua a falar, enchendo quase uma página com a sua conversação, antes de ir embora: "O piano acabara; ouviu-se um burburinho discreto de aplauso e conversação." (ASSIS, 1959a, p. 156-157).

Além da função da música como acompanhamento de cenas dos romances e como parte da caracterização das personagens, Machado, à medida que vai envelhecendo, fica cada vez mais cônscio da distância que o 
Machado de Assis em Linha - Universidade de São Paulo

http://machadodeassis.fflch.usp.br

separa da sua juventude e começa a empregá-la como um elemento associativo que pode ligar o presente com épocas já desaparecidas. Serve como um meio para estabelecer a continuidade temporal que parece ser um dos maiores problemas que procura solucionar nos romances a partir de Brás Cubas. Num episódio desse romance, um nordestino, visitando a Corte depois de muitos anos, lembra a música popular na geração passada, representada pela ópera Ana Bolena, e exprime o desejo de ouvir Ernani, provavelmente apresentada numa temporada mais recente (ASSIS, 1959a, p. 505). Machado frequentemente procura ligar o passado com o presente por meio da música popular ou folclórica e pregões. Pela introdução dessa nota popular, ele se aparta da técnica do Alencar dos romances da vida urbana e se aproxima dos romancistas regionalistas - Alencar, naturalmente, Franklin Távora, Inglês de Sousa, cujos romances regionalistas, exceto Lourenço, datam da década de 1870. Em Dom Casmurro, o pregão do preto que vende cocadas faz com que a menina Capitu recorde que é pobre, e portanto ela duvida que possa ter certeza do amor do Bento. Ao ouvir a voz do preto,

Chora, menina, chora,

Chora, porque não tem

Vintém,

ela recusa os doces que Bento lhe oferece, dizendo: "Se eu fosse rica, você fugia, metia-se no paquete e ia para a Europa" (ASSIS, 1959a, p. 748). Anos depois, quando são casados, Bento se refere várias vezes ao mesmo episódio (ASSIS, 1959a, p. 793, 849 e 853). A lembrança parece desgostar Capitu, mas traz saudades para o marido, saudades que percebemos são da sua vida de menino inocente. No princípio do Memorial, o conselheiro Aires ouve o pregão de um vassoureiro, que recorda várias vezes através do livro (ASSIS, 1959a, p. 1029 e 1052). Depois, o mesmo diplomata, em Esaú e Jacó, pensando no tempo em que estava destacado em Caracas, lembra certa sevilhana com quem passou um dia, e a memória vem acompanhada e reforçada por uma melodia que ela cantou:

Tienen las sevillanas

En la mantilla,

Un letrero que dice:

¡Viva Sevilla! 
Machado de Assis em Linha - Universidade de São Paulo

http://machadodeassis.fflch.usp.br

[...] A sombra da moça varreu tudo o mais, a rua, a gente, o gatuno, para ficar só diante do velho Aires, dando aos quadris e cantarolando a trova andaluza:

Tienen las sevillanas

En la mantilla... (ASSIS, 1959a, p. 926)

Aqui, a letra é insignificante em si, como também é insignificante a letra da quadra de "Cantiga velha", conto em que o contista, ao ouvir uma cantiga, relata uma história de sua mocidade, que a música lhe traz à lembrança. Em ambos os casos, através do processo associativo, o narrador consegue reconstituir uma parte da vida anterior e, unindo dois planos de tempo, cancelar os anos que os separam (RIEDEL, 1959, p. 66-102). A música popular, porém, não serve apenas para substituir o tempo cronológico pelo tempo psicológico, mas também pode servir de harmonia ou orquestração para a trama da obra, introduzindo assim no subconsciente do leitor elementos que aumentam a profundidade da ideia e o efeito psicológico da ação. Através desse processo, o autor apresenta em mais de um caso a indiferença do mundo para o drama do indivíduo. No episódio do princípio de Esaú e Jacó, Natividade e Perpétua ouvem da boca da cabocla do morro do Castelo a profecia que os "filhos serão gloriosos". Enquanto isso, o pai da profetisa, representando o mundo, para assim dizer, demonstra a sua falta de interesse, murmurando uma cantiga do sertão:

Menina da saia branca,

Saltadeira de riacho,

Trepa-me neste coqueiro,

Bota-me os cocos abaixo. (ASSIS, 1959a, p. 877-878)

Em Quincas Borba, a indiferença do criado diante da loucura de Rubião é representada pela polca que assobia durante a visita de Sofia e Fernanda à casa vazia de Rubião, quando elas estão discutindo o triste caso do dono (ASSIS, 1959a, p. 718-719). Embora as classes trabalhadoras quase que não apareçam nos maiores romances e contos de Machado, a música popular - as cantilenas africanas do Raimundo em Iaiá Garcia, os pregões em tantas obras, a canção da lavadeira em "Cantiga velha" - não nos deixa esquecer a sua existência, e essas músicas populares simbolizam, ouvidas entre bastidores, os alicerces do sistema social. Eugênio Gomes, estudando a preocupação de Machado com o problema da comunicação do que o "uso comum da linguagem não consegue definir", explica como, através de 
Machado de Assis em Linha - Universidade de São Paulo

http://machadodeassis.fflch.usp.br

metáforas, de combinações inusitadas de palavras e de gestos e expressões faciais, o leitor pode tirar ilações que as palavras não exprimem (GOMES, 1958, p. 156). Não há dúvida que, com esse propósito, Machado também apelou para todos os recursos musicais de que dispunha.

Aproximando-se do fim da sua carreira, esses recursos não eram poucos, abrangendo familiaridade com a música popular, pregões, óperas e a música instrumental e sinfônica que se ia tornando mais apreciada no Rio do último quartel do século. Não sabia tocar instrumento nenhum, não conhecia teoria musical, mas tinha escutado muita música com o seu ouvido de homem inteligente e conhecia compositores e artistas. Em 1896, numa crônica na Semana, Machado comentou a alta qualidade dos concertos em que foram apresentados os grandes mestres clássicos ao público brasileiro e escreve com muita emoção sobre dois solistas, Moreira de Sá e Viana da Mota, e o regente Alberto Nepomuceno, que em 1896 fora nomeado diretor da orquestra da Sociedade de Concertos Populares (ALMEIDA, 1942, p. 430). Nepomuceno, além de ser regente de orquestra, era compositor, tendo estudado na Alemanha e em Paris, donde voltara em 1895 para o Brasil. Lá participou na campanha organizada para propalar a música de Wagner, cujas óperas Lohengrin e Tannhäuser foram cantadas em 1883 e 1892; Die Meistersinger seria levado em 1905, quando Machado ainda existia.

Machado não permanecera indiferente à música alemã, e embora houvesse poucas oportunidades de ouvir as óperas, terá podido discuti-las com os amigos que eram músicos, e esses conhecimentos o terão animado a introduzir a música alemã nos seus últimos livros, até chegar ao ponto de, em Memorial de Aires, quase não se referir a outra música exceto a alemã, ou a outros compositores que não fossem os alemães. Não é demais dizer que esse romance foi escrito sob influência da música de Wagner e que a temática, estrutura e trama revelam um estudo profundo do drama musical Tristan und Isolde. Embora Tristan não fosse ouvido até depois da morte de Machado, podemos supor que Nepomuceno, Francisco Braga ou Leopoldo Miguez terão levado a partitura para o seu conhecimento, e que também, através de artigos, conversações, versões instrumentais e até composições imitativas, ele terá se familiarizado tanto com a ópera que não seria inexato afirmar que o Memorial pode ser o Tristan und Isolde de Machado.

No Memorial há elementos estruturais que lembram as técnicas especificamente musicais de Wagner, e há outros, dramáticos ou literários, que recordam a ação e as personagens do drama musical. A persistência do tema da separação, a presença inusitada - para Machado - do tema do mar, 
Machado de Assis em Linha - Universidade de São Paulo

http://machadodeassis.fflch.usp.br

os nomes dos protagonistas, o emprego de motivos poéticos e musicais que lembram os leitmotiven wagnerianos, tudo leva a crer que Machado havia estudado profundamente a ópera. A ação de Tristan und Isolde é simples: Tristan, afilhado do rei Mark de Cornwall, a quem o moço ama como um filho, viaja até a Irlanda, para encontrar Isolde, princesa irlandesa, e escoltála para Cornwall, onde há de casar com o rei. No barco, sob a influência de uma poção de amor, ele se torna amante de Isolde. Revelada sua traição, num confronto com o rei Mark, Tristan morre, ferido por um dos cavaleiros do rei, que dizia ser seu amigo. O rei, informado da situação, lamenta o sucedido, dizendo que se soubesse que os jovens se amavam, teria cedido Isolde para Tristan. Com respeito à música, se deve notar que a partitura está construída de uma série de frases ou melodias chamadas leitmotiven, que simbolizam situações dramáticas ou características pessoais das personagens e que, reaparecendo frequentemente, sublinham as ideias dramáticas e produzem a unidade e a coesão dramáticas e musicais da ópera. Há uma série de solos vocais, que culminam nos grandes duetos do segundo e terceiro atos, cantados pelos protagonistas. A ópera é fundamentalmente aristocrática, mas uma nota popular é introduzida no primeiro ato, que começa com uma cantiga de pastores. O ponto de vista é o dos trágicos amantes e, portanto, eminentemente romântico, e a ação dos três atos se realiza num barco ou à beira-mar. Há tantos elementos no Memorial sugestivos da ópera que seria difícil não acreditar que Machado não só estivesse escrevendo sob a influência de Wagner, mas também estivesse procurando compor em termos da realidade carioca uma refundição da ópera quase tão complexa como o original. Os nomes dos protagonistas são tirados de óperas alemãs: Tristão, da ópera de Wagner, e Fidélia, do Fidélio de Beethoven. Temendo que o leitor não preste a devida atenção ao significado dos nomes, Machado procura espertar-lhe o entendimento com breves sugestões. Com respeito ao nome Fidélia, ele diz: "Terá sido dado à filha do barão, como a forma feminina de Fidélio, em homenagem a Beethoven"? (ASSIS, 1959a, p. 1044). Visto que tantas outras heroínas dos romances têm nomes que, como Fidélia, são de origem latina, ele julgou necessário incluir esse comentário, para não deixar lugar a dúvidas. Respeito ao nome Tristão, Machado em um lugar o liga - muito sutilmente - ao nome do compositor:

Tristão conhece música, e à noite, a pedido dela, executou ao piano um pedaço de Wagner, que ele achou muito bem. Além do Campos, jantou lá um padre Bessa, o que batizou Tristão. (ASSIS, 1959a, p. 1065) 
Machado de Assis em Linha - Universidade de São Paulo

http://machadodeassis.fflch.usp.br

Logo no princípio do romance, lembramos o ambiente medieval da ópera, ao ler as duas epígrafes, que são tiradas de cantigas de amigo. A primeira também desempenha a importante função de introduzir, antes do começo do livro, o tema do mar:

Em Lixboa sobre lo mar,

Barcas novas mandey lavrar...

Este tema reaparece através do livro, mediante referências às viagens de Tristão - inclusive o curto passeio de Tristão e do conselheiro para Niterói - e o curioso episódio do quadro que Fidélia pinta, à sugestão de Tristão (ASSIS, 1959a, p. 1067). Ele quer um trecho marinho com serra ao longe, e Aires propõe a inclusão no quadro de uma figura humana, a de Tristão (ASSIS, 1959a, p. 1093). Finalmente, há um momento em que a temática marítima é ligada à da música, quando, perto do fim, Tristão e Fidélia tocam piano e depois saem à praia (ASSIS, 1959a, p. 1124).

Nos romances de Machado são inseridos muitos sonhos, cujo propósito é de simbolizar ideias que não podiam ser apresentadas diretamente, segundo os cânones do romance realista praticado por Machado. Num sonho, Fidélia vê, ao fundo de uma enseada, a aparição de duas figuras, o pai e o sogro, que "vieram [...] sobre a água, de mãos dadas, até que pararam diante dela, na praia." (ASSIS, 1959a, p. 1065). O pai e o pai do marido falecido evidentemente representam o esposo que ela deseja e que vai surgir do mar. É uma referência a Tristão, que acaba de chegar de Lisboa no paquete inglês. No princípio da ópera, Tristan, o marido desejado de Isolde, chega à Irlanda num barco. É ainda mais interessante cotejar o sonho com o episódio no fim da ópera, quando depois da morte de Tristão, o rei Mark diz a Isolde que vinha para o castelo de Tristão no intuito de entregar Isolde a ele. A ideia da substituição do velho pelo jovem é proposta também pelo próprio conselheiro no episódio do quadro, em que ele recomenda a Fidélia a inclusão da figura de Tristão - gesto simbólico de renúncia. Aqui convém assinalar que existe entre Aires e Tristão uma relação de pai e filho, à semelhança da existente entre o rei Mark e Tristan. Em certa altura, o conselheiro escreve no seu diário: "Tristão me confiaria, creio, visto que entro cada vez mais no coração daquele moço. Ouve-me, fala-me, busca-me, quer os meus conselhos e opiniões." (ASSIS, 1959a, p. 1113).

O elemento da música tem a maior importância em Memorial de Aires, os únicos compositores mencionados sendo alemães: Wagner, naturalmente, e também Schubert e Mozart. Se lembrarmos que os protagonistas são 
Machado de Assis em Linha - Universidade de São Paulo http://machadodeassis.fflch.usp.br

pianistas, e se considerarmos a maneira como a música é utilizada, podemos concluir que a música de piano simboliza o amor: Fidélia, depois da morte do primeiro marido, deixara de tocar, e só começou de novo uma noite por instância de Tristão, que acabava de tocar um trecho de Mozart; no dia seguinte, às sete horas da manhã, voltou ao piano. Nasce aqui o tema do dueto que os dois jovens tocam, exprimindo o seu amor mútuo, e lembrando o glorioso dueto do segundo ato da ópera. Simbolizando assim o amor, a música forma parte da estrutura do livro (ASSIS, 1959a, p. 1028, 1052 e 1071). O conselheiro, objeto da afeição de todos, é excluído do amor, e por isso o autor enfatiza que Aires não sabe música, por nunca tê-la aprendido. Já citei o parágrafo em que exprime o seu pesar de não tê-la estudado, tema a que volta mais tarde: "ah! se eu soubesse música! Pegava do violino, trancava bem as portas para não ser ouvido da vizinhança, e deixava-me ir atrás do arco." (ASSIS, 1959a, p. 1074). Não está dizendo que, se soubesse ou pudesse amar, seria rival de Tristão? Mas não sabe música; exprime-se com palavras, repetindo muitas vezes um refrão, ou parte dele, que simboliza a sua incapacidade de amar, ideia ligada à da sua velhice de sexagenário; é um lindo verso de Shelley: "I cannot give what men call love." (ASSIS, 1959a, p. 1035). ${ }^{3}$

Eugênio Gomes (1958, p. 172), no seu ensaio "Aires e o amor", diz que "nesse derradeiro e dissimulado amor de Aires não havia nada de espiritual", considerando-o "uma secreta, mas atormentadora paixão." Se essa interpretação é exata, surge a ideia de uma possível diminuição do vigor sexual de Aires, que ele aceita como uma consequência da sua velhice. Nesse sentido, seria interessante considerar o verso em relação ao contexto em que vem citado aqui e em outros lugares e a maneira como Shelley o cita. No começo do Memorial, Machado se refere a Shelley e pouco depois cita o verso, que não torna a citar na íntegra. Mais adiante, repete as primeiras palavras, "I can give not...", depois menciona o verso, sem citá-lo, e perto do fim, repete só as duas primeiras palavras, "I can...", num contexto que evidentemente demonstra a importância da eliminação da palavra "not"; ele e Fidélia, tendo-se sentado num canapé, "ficamos a olhar um para o outro, ela desfeita em graça, eu desmentindo Shelley com todas as forças sexagenárias restantes." (ASSIS, 1959a, p. 1033, 1046, 1115 e 1129). Aqui, por um momento, pensa que o amor - o que os homens chamam amor - é possível, mas Fidélia e Tristão partem e Aires se conforma com a situação, dizendo para um

\footnotetext{
${ }^{3}$ Mais de uma vez, ao longo deste parágrafo, Sayers refere-se equivocadamente os versos de Shelley. A citação correta é "I can give not what men call love." (N. do E.)
} 
Machado de Assis em Linha - Universidade de São Paulo

http://machadodeassis.fflch.usp.br

amigo, em mais uma expressão de renúncia, "que a mocidade tem o direito de viver e amar, e separar-se alegremente do extinto e do caduco." (ASSIS, 1959a, p. 1129). Devemos notar aqui que Machado trata o verso ou motivo musicalmente, variando-o e modificando-o para produzir diversos efeitos, passando da melancolia da negativa para a alegria da afirmativa, efeitos que podiam ser realizados por um compositor pela modificação do ritmo ou da clave.

O Memorial termina numa clave menor, mas não com a mesma nota trágica do drama musical de Wagner. A tragédia de Tristan und Isolde é produzida pela morte dos jovens amantes, que é, também, a morte simbólica do amor e da juventude. Machado, na sua refundição da ópera, muda o ponto de vista para apresentar uma tragédia menos intensa, mas de igual transcendência simbólica, a rejeição da velhice pela juventude, e a consequente separação, solidão e saudade, sendo esta a palavra dominante da última frase do livro. Lúcia Miguel Pereira (1939, p. 309) diz que o livro é autobiográfico. Machado se representa na figura do conselheiro, e Carolina é D. Carmo. A biógrafa de Machado observa que Machado amava D. Carmo oficialmente, mas que há 167 trocas de nome entre Carmo e Fidélia, provavelmente porque "cada vez que pensava numa, a figura da outra lhe acudia ao espírito, como se as confundisse". Essas trocas só cessam quando Aires reconhece o amor de Fidélia por Tristão. Parece-me igualmente evidente que Carmo e Fidélia são a mesma pessoa, representando Carolina na mocidade e na velhice. Assim, o casamento e a partida de Fidélia representam a dupla separação de Machado da mulher que amava, da Carolina jovem, vítima da ação corrosiva do tempo, e da Carolina velha, vítima da morte. Dela só lhe restam saudades ou sonhos, como aquele em que Fidélia aparece a Aires e ele lhe toma as mãos por um instante. O sonho termina quando Aires é acordado pelo pregão do vassoureiro (ASSIS, 1959a, p. 1052). Aires - Machado - é o viúvo rei Mark, a quem só restam na velhice as memórias do amor e da amizade. Ao meu ver, Machado queria fazer do Memorial não a história de um amor juvenil e quase banal, mas a biografia de Aires, o velho que não sabia música, mas que vivia cheio de poesia e de reminiscências, tal qual o próprio autor.

\section{Referências}

ALMEIDA, Renato de. História da música brasileira. 2. ed. Rio de Janeiro: Briguiet, 1942 
Machado de Assis em Linha — Universidade de São Paulo

http://machadodeassis.fflch.usp.br

ASSIS, Machado de. Crônica. Rio de Janeiro: Jackson, 1942a. v. 1.

. Crônica. Rio de Janeiro: Jackson, 1942b. v. 2. . Crítica teatral. Rio de Janeiro: Jackson, 1944. . Obra completa. Ed. Afrânio Coutinho. Rio de Janeiro: Aguilar, 1959a. v. 1. . Obra completa. Ed. Afrânio Coutinho. Rio de Janeiro: Aguilar, 1959b. v. 2. . Obra completa. Ed. Afrânio Coutinho. Rio de Janeiro: Aguilar, 1959c. v. 3. . Dispersos de Machado de Assis. Org. Jean-Michel Massa. Rio de Janeiro: Instituto Nacional do Livro, 1965.

AZEVÊDO, Luiz Heitor Corrêa de. 150 anos de música no Brasil. Rio de Janeiro: José Olympio, 1956.

BIBLIOTECA NACIONAL. A música no Rio de Janeiro imperial (1822-1870). Apresentação de Adonias Filho. Rio de Janeiro: Biblioteca Nacional, 1962.

FRIAS, Sanches de. Artur Napoleão. Lisboa, 1913.

GOMES, Eugênio. Machado de Assis. Rio de Janeiro: São José, 1958.

MINISTÉRIO DA EDUCAÇÃO E SAÚDE. Exposição Machado de Assis. Rio de Janeiro: Ministério da Educação e Saúde, 1939.

PEREIRA, Lúcia Miguel. Machado de Assis: estudo crítico e biográfico. Rio de Janeiro: Companhia Editora Nacional, 1939.

RIEDEL, Dirce Côrtes. O tempo no romance machadiano. Rio de Janeiro: São José, 1959.

SILVA, Lafayette. História do teatro brasileiro. Rio de Janeiro: Ministério da Educação e Saúde, 1938.

SOUSA, José Galante de. Fontes para o estudo de Machado de Assis. Rio de Janeiro: Instituto Nacional do Livro, 1958.

THOMPSON, Oscar. Sonata. In: __. International Cyclopedia of Music and Musicians. 7th ed. ver. New York: Dodd, Mead \& Co., 1956. 